\title{
EFEKTIVITAS PESTISIDA ORGANIK EKSTRAK KULIT JERUK NIPIS TERHADAP KEMATIAN JANGKRIK
}

\author{
Rudi Firyanto*, MF Sri Mulyaningsih, Laura Nisa \\ Program Studi Teknik Kimia Fakultas Teknik Universitas 17 Agustus 1945 (UNTAG) Semarang \\ Jl. Pawiyatan Luhur Bendan Duwur, Semarang 50233. \\ "Email: rudi-firyanto@untagsmg.ac.id
}

\begin{abstract}
Abstrak
Pestisida organik adalah pestisida yang bahan dasarnya berasal dari tumbuhan yang bersifat mudah terurai di alam. Salah satu tumbuhan yang dapat dijadikan bahan baku pembuatan pestisida organik adalah kulit jeruk nipis. Kulit jeruk dapat berpotensi menjadi repellent karena mengandung minyak atsiri dengan komponen limonene, mirsen, linalool, oktanal, decanal, sitronelol, neral, geraniol, valensen dan sinensial. Linalool, sitronelol dan geraniol termasuk senyawa yang bersifat repellent terhadap serangga (arthropoda). Pengunaan bahan alami dari ekstrak kulit jeruk diharapkan lebih aman jika dibandingkan dengan bahan kimia Dichloro Diphenyl Trichloroethane (DDT). Proses pembuatan pestisida organik dilakukan dengan ekstraksi maserasi menggunakan ethanol sebagai pelarut. Dalam penelitian ini bertujuan untuk mengetahui pengaruh variabel terhadap hasil pengujian pestisida organic terhadap jangkrik. Hasil penelitian menunjukkan pada konsentrasi pestisida organic 5\% didapatkan prosentase kematian jangkrik $72 \%$, pada konsentrasi $15 \%$ didapatkan prosen kematian jangkrik $80 \%$, dan pada konsentrasi $25 \%$ didapatkan prosen kematian jangkrik $88 \%$. Hasil penelitian menunjukkan bahwa adanya pengaruh terhadap perbedaan konsentrasi pestisida organic terhadap kematian jangkrik.
\end{abstract}

Kata kunci: jeruk nipis, maserasi, pestisida organik

\begin{abstract}
Organic pesticides are pesticides whose basic ingredients come from plants that are easily biodegradable in nature. One of the plants that can be used as raw material for making organic pesticides is lime peel. Orange peel can potentially be a repellent because it contains essential oils with components of limonene, mirsen, linalool, octanal, decanal, citronellol, neral, geraniol, valensen and sinensial. Linalool, citronellol and geraniol are compounds that are repellent to insects (arthropoda). The use of natural ingredients from orange peel extract is expected to be safer when compared to the chemical Dichloro Diphenyl Trichloroethane $(D D T)$. The process of making organic pesticides is done by maceration extraction using ethanol as a solvent. This study aims to determine the effect of variables on the results of testing organic pesticides on crickets. The results showed that at 5\% organic pesticide concentration, $72 \%$ of crickets died, at $15 \%, 80 \%$ of crickets died, and at $25 \%, 88 \%$ of crickets died. The results showed that there was an effect on differences in the concentration of organic pesticides on the mortality of crickets..
\end{abstract}

Keywords: lime, maceration, organic pesticide

\section{PENDAHULUAN}

Pestisida adalah substansi kimia dan bahan lain yang digunakan untuk mengendalikan berbagai hama. Bagi petani jenis hama yaitu tungau, tumbuhan pengganggu, penyakit tanaman yang disebabkan oleh fungi (jamur), bakteria, dan virus, nematoda (cacing yang merusak akar), siput, tikus, burung dan hewan lain yang dianggap merugikan (Djojosumarto, 2000). Dahulunya, manusia menggunakan pestisida nabati dalam pembasmian hama, namun sejak ditemukannya Dichloro Diphenyl Trichloroethane (DDT) tahun 1939, penggunaan pestisida nabati sedikit demi sedikit ditinggalkan sehingga manusia beralih ke pestisida kimia. Penggunaan pestisida kimia secara terus - menerus menimbulkan dampak buruk dari segi lingkungan maupun dari segi kesehatan manusia

Penggunaan pestisida kimia yang dinilai praktis untuk mengendalikan serangan hama, ternyata membawa dampak negatif bagi lingkungan sekitar bahkan bagi penggunanya sendiri. Sehingga dibutuhkan suatu alternatif lain yang tidak berdampak negatif seperti pestisida nabati yang ramah lingkungan (Alqodar, 2008). Pestisida nabati adalah pestisida yang bahan dasarnya berasal dari tumbuhan 
yang relatif mudah dibuat dengan kemampuan yang terbatas, karena pestisida nabati ini bersifat mudah terurai di alam sehingga tidak mencemari lingkungan dan relatif aman bagi manusia, serta ternak. Pestisida nabati ini berperan sebagai racun kontak dan racun perut (Anonim, 2007).

Pestisida nabati adalah pestisida yang bahan dasarnya berasal dari tanaman. Salah satu tanaman yang dapat digunakan sebagai pestisida organik adalah kulit jeruk. Pada penelitian sebelumnya yang dilakukan (Mursiah, 2020) terbukti ekstrak kulit jeruk nipis dapat menjadi pestisida organik untuk memberantas serangga belalang dengan konsentrasi 5,55\% dan konsentarasi 9,96\%. Kulit jeruk dapat berpotensi menjadi repellent (Wager, 2020) karena mengandung minyak atsiri dengan komponen limonene, mirsen, linalol, oktanal, decanal, sitronelol, neral, geraniol, valensen, sinnsial dan sinensial (Menristek, 2020). Linalol, citronellal dan geraniol termasuk senyawa yang bersifat repellent terhadap serangga (Inayah, 2020). Ekstrak sederhana kulit jeruk dengan perendaman menggunakan aquades dan penyaringan dapat langsung dengan mudah diaplikasikan (Resti, 2010). Pengunaan bahan alami dari ekstrak kulit jeruk diharapkan lebih aman jika dibandingkan dengan bahan kimia Dichloro Diphenyl Trichloroethane (DDT).

Pestisida nabati sudah digunakan tiga abad yang lalu. Beberapa kelebihan pestisida nabati menurut Harjono (2009), daya kerjanya selektif, residu cepat terurai dan tidak beracun, tidak menimbulkan pencemaran air, tanah, udara dan tanaman, serangga-serangga berguna/predator tidak ikut musnah, tidak menimbulkan kekebalan serangga, murah dan mudah didapat. Sehingga biopestisida sering digunakan sebagai pengganti pestisida kimia dalam membasmi hama dan penyakit.

Menurut Kardiman (2000) mengungkapkan bahwa pembakuan pestisida nabati memang sedikit sulit dilakukan berbanding pertisida sintetik karena beberapa faktor.

Sifat Pestisida Nabati,

1. Merupakan produk alami sehingga umumnya bersifat spesifik dan mudah diterima kembali oleh alam (mudah terurai) sehingga tidak berbahaya bagi kesehatan manusia dan lingkungan karena residu mudah menghilang.

2. Fisiokimia dan dampak negatif terhadap lingkungan masih terbatas.
3. Bersifat "pukul rata" yaitu apabila diaplikasikan akan membunuh hama dan residu akan cepat hilang.

4. Dibuat atau diformulasikan dengan teknik sederhana.

Tujuan Penggunaan Pestisida Nabati,

1. Alternatif supaya penggunaan tidak terganggu pada pestisida sintetik tanpa meninggalkan dan menganggap tabu penggunaan pestisida sintetik.

2. Supaya penggunaan pestisida sintetik dapat diminimalkan sehingga kerusakan lingkungan karena penggunaan pestisida dapat dicegah.

Kelebihan dan Kekurangan Penggunaan Pestisida Nabati

1. Kelebihan utama penggunaan insektisida nabati adalah sifatnya yang cepat terurai atau terdegradasi oleh sinar matahari, udara serta kelembaban lingkungan sehingga tidak meninggalkan residu (Sukrasno, 2007). Kelebihan lain penggunaan insektisida nabati antara lain (Naria, 2005):

- Tidak meninggalkan residu pada komponen lingkungan dan bahan makanan.

- Dapat dibuat sendiri dengan cara yang sederhana.

- Bahan yang digunakan dapat disediakan sendiri di sekitar rumah.

- Secara ekonomis tentunya mengurangi biaya pembelian insektisida sintetis.

2. Sedangkan kekurangan penggunaan insektisida nabati, antara lain (Naria, 2005):

- Daya kerja insektisida relatif lambat sehingga harus diaplikasikan lebih sering. Efek mortalitas lambat karena daya racun yang rendah.

- Pestisida nabati memiliki bahan aktif yang kompleks sehingga tidak semua bahan aktif dapat terdeteksi.

- Pestisida nabati belum bisa diproduksi dalam jumlah besar karena keterbatasan bahan baku.

\section{METODOLOGI}

Rancangan percobaan proses pembuatan pestisida organik yang digunakan adalah Analysis of Variance (ANOVA). Analisis ANOVA ini adalah prosedur One Way ANOVA atau sering disebut dengan perancangan sebuah faktor, yang merupakan salah satu alat analisis statistik ANOVA yang bersifat satu arah (satu jalur). 
Variabel tetap yang digunakan adalah: massa kulit jeruk nipis 50 gram. Sedangkan variabel berubahnya: konsentrasi pestisida organik $5 \%, 15 \%$, dan $25 \%$.

Tahapan pembuatan pestisida organik dari kulit jeruk nipis meliputi:

1. Persiapan bahan baku

Mencuci kulit jeruk nipis dan potong menjadi ukuran lebih kecil untuk dikeringkan. Kulit jeruk nipis yang sudah kering dihaluskan dengan menggunakan blender.

2. Ekstraksi Maserasi

Serbuk kulit jeruk nipis sebanyak 50 gram dimasukkan dalam botol gelap dan direndam etanol $70 \%$ sebanyak $500 \mathrm{ml}$ selama 24 jam dan dilakukan pengadukan sesekali. Setelah 24 jam dilakukan penyaringan dan ampas yang dihasilkan di ekstraksi lagi dengan pelarut baru dengan prosedur sama seperti sebelumnya

3. Membuat ekstrak sesuai dengan konsentrasi pada variabel yang ditentukan.

Filtrat hasil ekstraksi diuapkan sampai menjadi ekstrak kental dan dilakukan pengenceran dengan konsentrasi 5\%, 15\%, dan $25 \%$.

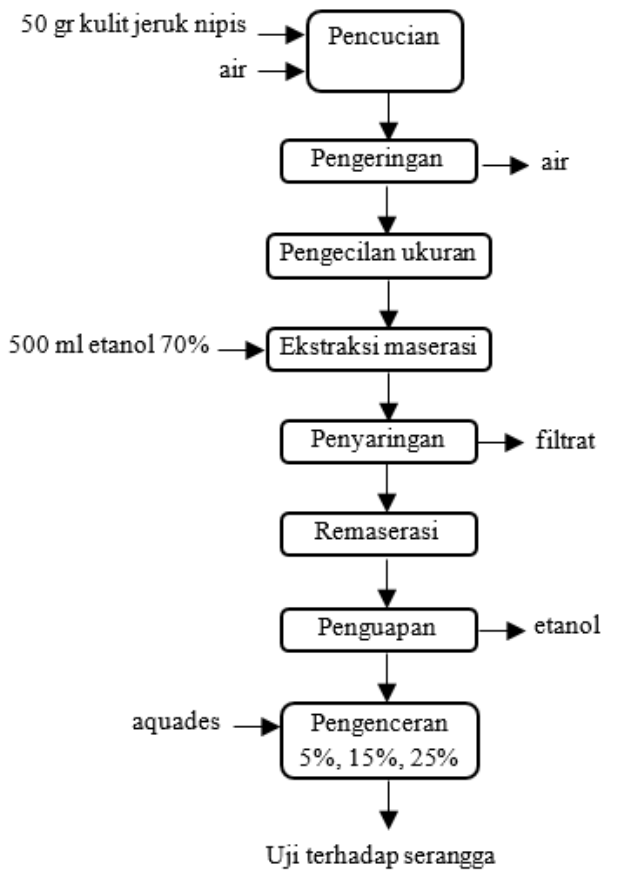

Gambar 1. Diagram Alir Percobaan

4. Pengujian terhadap jangkrik.

Jangkrik sebanyak 5 ekor dimasukkan kedalam toples plastik yang sudah dipersiapkan dan diberi daun pisang sebagai pakannya. Selanjutnya jangkrik yang ada didalam toples disemprotkan dengan ekstrak kulit jeruk nipis sesuai dengan konsentrasi yang telah ditentukan dengan interval waktu setiap 3 jam dilakukan penyemprotan 4 kali. Dan dilakukan pengamatan terhadap tingkah laku jangkrik dan berapa ekor yang mati.

\section{HASIL DAN PEMBAHASAN}

Berdasarkan hasil metode Analisa of variant (ANOVA), terdapat hubungan yang nyata antara perbedaan konsentrasi pestisida organik dari ekstrak kulit jeruk nipis terhadap kematian serangga jangkrik. Dari empat kali percobaan yang telah dilakukan dengan perlakuan konsentrasi ekstrak kulit jeruk nipis $(0 \%, 5 \%, 15 \%, 25 \%)$ didapatkan hasil uji pada kematian jangkrik dengan jumlah yang berbeda-beda seperti terlihat pada Gambar 2 . Pada perlakuan dengan konsentrasi ekstrak kulit jeruk nipis $0 \%$ tidak ditemukan kematian pada jangkrik.

Pada perlakuan dengan konsentrasi ekstrak kulit jeruk nipis 5\% didapatkan persentase kematian jangkrik sebanyak $72 \%$.

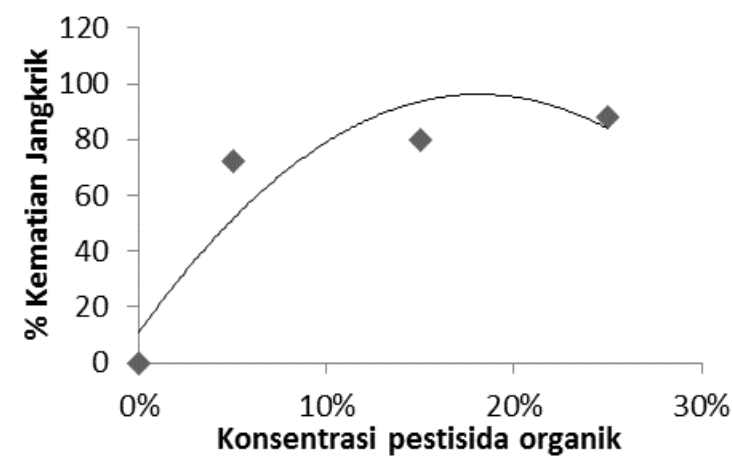

Gambar 2. Grafik Hubungan antara Perlakuan vs. \% Kematian Jangkrik

Pada perlakuan dengan konsentrasi ekstrak kulit jeruk nipis $15 \%$ didapatkan persentase kematian jangkrik sebanyak $80 \%$. Pada perlakuan dengan konsentrasi ekstrak kulit jeruk nipis 25\% didapatkan persentase kematian jangkrik sebanyak $88 \%$. Pada perlakuan dengan pestisida kimia didapatkan persentase kematian jangkrik sebanyak $92 \%$.

Dari hasil ekstraksi dengan metode maserasi didapatkan ekstrak kulit jeruk nipis sebanyak 8,016 gram dari 50 gram kulit jeruk nipis dengan pelarut etanol sebanyak $500 \mathrm{ml}$ dan rendemen/yield yang dihasilkan sebanyak $16,032 \%$. Dari hasil tersebut maka yield pada penelitian ini lebih banyak dari penelitian sebelumnya yang menghasilkan rendemen 
sebanyak $15,4 \%$ dari ekstraksi dengan metode maserasi.

Syarat mutu pestisida menurut SNI 016729-2002 pestisida nabati (tidak termasuk tembakau) diperbolehkan. Dari penelitian yang dilakukan ini menggunakan ekstrak kulit jeruk nipis sehingga pestisida nabati yang dihasilkan memenuhi syarat mutu pestisida menurut SNI 01-6729-2002.

\section{KESIMPULAN}

Dari hasil penelitian ini dapat disimpulkan bahwa pestisida organik yang diperoleh memiliki yield sebesar $16,032 \%$ dan terdapat pengaruh variabel pestisida organik, didapatkan persen kematian jangkrik tertinggi sebanyak 88\% dengan konsentrasi $25 \%$.

Pestisida organik yang dihasilkan, menggunakan bahan kulit jeruk nipis dan tidak terbuat dari tembakau, sehingga berdasarkan bahan yang digunakan tersebut sudah memenuhi syarat sebagai bahan pestisida menurut SNI 01-6729-2002.

\section{DAFTAR PUSTAKA}

Al-qodar, (2008), Pengaruh Perasan Daun Pepaya (Carica papaya, liin) Terhadap Hama Bayam Cabut (Amaranthus Tricolor $\mathrm{Sp}$.).

Anonim. (2007), Pengendalian Hama dan Penyakit dengan Pestisida Organik Terhadap Sayur dan Buah. Departemen Kesehatan RI, Direktorat Jendral Pengawasan Obatdan Makanan, Jakarta.

Djojosumarto, (2000), Teknik Aplikasi Pertanian. Penerbit Kanisius.

Harjono I., (1999), Sistem Pertanian Organic. Solo : Aneka.

Inayah, Mengenal Geraniol dan Sitronellol. www.anekaplanta.wordpress.com/2007/1 2/26/mengenalgeranioldan-sitronelol/. Diakses: 25 Februari 2020, jam 14.40

Kardinan, Agus, (2000), Pestisida Nabati: Ramuan dan Aplikasi, Penebar Swadaya, Jakarta.

Menristek Bidang Pendayagunaan dan Pemasyarakatan Ilmu Pengetahuan dan Teknologi Minyak kulit jeruk. www.opensource.telkomspeedy.com/rep o/abba/v12/artikel/panganDIPPTI/minya k_kulit_jeruk.pdf. Diakses: 23 Februari 2020, jam 08.10

Mursiah, Studi Pestisida Botani Kulit Jeruk Nipis. $\quad$ www.docplayer.info/56726504Studi-pestisida-botani-kulit-jeruk-nipis- citrus-aurantifolia-swingle-terhadap-2jenis-belalang.html. Diakses: 22 Februari 2020, jam 10:00

Naria, E., (2005), Insektisida nabati untuk rumah tangga. Jurnal Kesehatan Masyarakat.

Resti, S.E.S., Fajari, M. dan Afiq, D.A., (2010), Ekstraksi minyak atsiri dari limbah kulit Daya Proteksi Ekstrak Kulit Jeruk Purut (Citrus hystrix) Terhadap Nyamuk Demam berdarah 185 jeruk manis di Desa Gadingkulon Kecamatan Dau Kabupaten Malang sebagai campuran minyak goreng untuk penambah aroma jeruk. Universitas Negeri Malang, Malang.

Sukrasno \& Tim Lentera, (2007), Mimba Tanaman Obat Multifungsi, Jakarta: Agromedia Pustaka

Wager, K., Organic mosquitos repellent: Lemon.

www.dailypuppy.com/articles/organicmosquito-repellentlemon/6c2bee5a-df04b9af-65ffd1600bc5d77b, Diakses: 22 Februari 2020, jam 10.15. 